\title{
Komunikasi real-time menggunakan bluetooth low energi untuk pengendara roda dua
}

\author{
Mayer $^{1 *}$, Griffani Megiyanto Rahmatullah ${ }^{2}$, Sanam Herlambang ${ }^{3}$ \\ 1,2,3 Jurusan Teknik Elektro, Politeknik Negeri Bandung \\ Jl. Gegerkalong Hilir, Ciwaruga, Kec. Parongpong, Kabupaten Bandung Barat, Jawa Barat, Indonesia \\ 1*mayer.tcom417@polban.ac.id, ${ }^{2}$ griffani.megiyanto@ polban.ac.id, ${ }^{3}$ sanam.herlambang @ polban.ac.id
}

\begin{abstract}
ABSTRAK
Komunikasi antara pengendara dan penumpang pada kendaraan roda dua sulit dilakukan mengingat banyaknya faktor gangguan seperti noise dari lingkungan jalan. Padahal komunikasi ini penting dilakukan, khususnya pada kendaraan ojek online. Pada penelitian ini, bluetooth low energy (BLE) akan digunakan sebagai media komunikasi suara dua arah untuk pengendara dan penumpang kendaraan roda dua. Sistem dirancang menggunakan mikrokontoler Robotdyn dan Node MCU sebagai pengelola data, MAX9814 sebagai input suara, dan HC-42 sebagai media transmisi antara pengirim dan penerima maupun sebaliknya. Realisasi alat menggunakan box hitam dengan diameter $10 \times 7,5 \times 3 \mathrm{~cm}$ yang ditempelkan pada sebuah helm. Pengujian dilakukan untuk mengukur delay, kestabilan sistem, dan konsumsi daya yang digunakan. Hasil yang diperoleh adalah delay yang diterima sebesar $125 \mathrm{~ms}$ dengan lama kestabilan sistem selama mengirimkan sebesar 10858,5 ms dan konsumsi daya yang digunakan kurang dari $400 \mathrm{~mW}$.
\end{abstract}

Kata kunci: bluetooth low energy, komunikasi suara, MAX9814, HC-42

\section{ABSTRACT}

Communication between drivers and passengers on two-wheeled vehicles is difficult given the many factors of interference such as noise from the road environment. Even though this communication is important, especially on online motorcycle taxis. In this study, bluetooth low energy (BLE) will be used as a two-way voice communication medium for drivers and passengers of two-wheeled vehicles. The system is designed using Robotdyn microcontroller and Node MCU as data manager, MAX9814 as voice input, and HC-42 as transmission medium between sender and receiver and vice versa. The realization of the tool uses a black box with a diameter of $10 \times 7.5 \times 3 \mathrm{~cm}$ which is attached to a helmet. Tests are carried out to measure delay, system stability, and power consumption. The results obtained are the received delay of $125 \mathrm{~ms}$ with a long system stability during transmission of $10858.5 \mathrm{~ms}$ and the power consumption used is less than $400 \mathrm{~mW}$.

Keywords: bluetooth low energy, voice communication, MAX9814, HC-42

\section{PENDAHULUAN}

Komunikasi suara merupakan komunikasi yang sering digunakan manusia untuk berkomunikasi satu dengan yang lain secara real-time. Komunikasi suara membantu manusia agar saling mendapatkan informasi yang cepat dalam waktu yang singkat. Ini sangat dibutuhkan dalam berbagai bidang pekerjaan yang membutuhkan waktu yang cepat untuk mendapatkan informasi. Salah satu pekerjaan yang membutuhkan informasi cepat adalah ojek online. Komunikasi membantu pengendara roda dua mengetahui keinginan pelanggan dalam menjalankan pekerjaannya, seperti pemberitahuan arah jalan, tempat berhenti penumpang, dan sebagainya. Selain itu ketika mengantarkan penumpang, pengendara akan sulit berkomunikasi dengan penumpang mengenai arah tujuan maupun percakapan lain yang diakibatkan noise dari luar berupa suara dari lingkungan jalan dan redaman suara pada busa helm. Komunikasi langsung antara penumpang dan pengendara tanpa menggunakan alat bantu dinilai kurang efektif. Selain karena noise yang terjadi di jalan raya komunikasi secara langgung ini juga dapat mengganggu konsentrasi pengemudi untuk menerima pesan suara dan mencerna pesan suara yang diberikan oleh penumpang. Kegiatan ini cukup berisiko terjadinya kecelakaan lalu lintas seperti yang dilaporkan oleh Bappeda Yogyakarta dimana mencapai 2.147 kejadian selama tahun 2021 [1]. 
Dengan demikian, dalam menjalankan kebutuhan komunikasi antara penumpang dan pengemudi dibutuhkan cara yang efektif agar tidak membuat terjadinya kesalahpahaman informasi yang diberikan penumpang dan pengendara, serta meminimalisir terjadinya kejadian kecelakaan lalu lintas.

Salah satu media komunikasi jarak dekat yang dapat dimanfaatkan adalah bluetooth. Penggunaan bluetooth biasanya digunakan untuk kegiatan mengontrol benda atau mendapatkan hasil nilai dari sebuah sensor [2], [3]. Implementasi komunikasi suara menggunakan bluetooth pada helm telah dilakukan dan digunakan untuk membantu pengendara menentukan navigasi yang dibantu oleh google maps dan sebagai pengirim data berupa lokasi jika sewaktu-waktu terjadi kecelakaan [4]. Pemilihan bluetooth sebagai media komunikasi suara karena memiliki fitur untuk melakukan komunikasi berbasis pulse code modulation (PCM) [5]. Terlebih lagi saat ini telah muncul bluetooth low energy (BLE) dimana daya yang digunakan lebih rendah jika dibandingkan dengan bluetooth klasik [6]. Hal ini juga didukung penelitian [7] dimana membandingkan konsumsi daya dan tingkat akurasi dari BLE dan WiFi.

Penelitian ini mengusulkan sebuah sistem komunikasi berbasis BLE untuk kebutuhan pengendara roda dua. Sistem yang diusulkan adalah menggunakan bluetooth sebagai media transmisi suara. Penelitian ini dilakukan dengan membuat dua buah perangkat komunikasi yang nantinya akan disambungkan satu dengan yang lain dengan menggunakan bluetooth versi 5.0 atau BLE. Suara yang diterima oleh mikrofon akan dikonversi menjadi data sebelum dikirimkan melalui protokol bluetooth lalu konversi kembali menjadi suara sesudah diterima oleh penerima dan dikeluarkan oleh speaker. Dengan sistem ini, maka komunikasi suara antara pengendara dan penumpang pada kendaraan roda dua dapat lebih efektif.

\section{METODE PENELITIAN}

\subsection{Perancangan Blok Diagram}

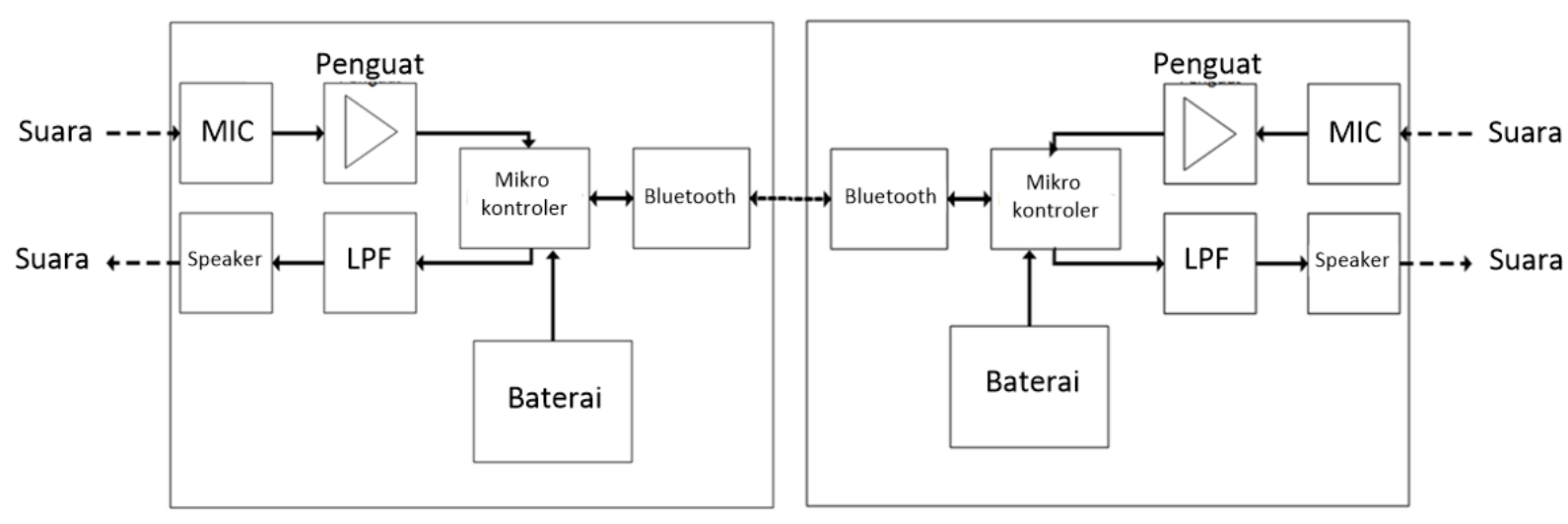

Gambar 1. Diagram blok sistem

Gambar 1 menampilkan diagram blok sistem yang akan dirancang. Pada bagian pengirim maupun penerima memiliki blok diagram yang sama. Suara akan masuk melalui microphone dan dinaikkan nilai amplitudonya menggunakan penguat yang terdapat pada microphone. Selanjutnya akan dilakukan sampling pada suara dan diubah menjadi digital menggunakan mikrokontroler agar dapat ditransmisikan menggunakan bluetooth. Selanjutnya mikrokontroler akan memerintahkan bluetooth mengirim data digital ke penerima dan data digital pada penerima akan diubah menjadi deretan bit yang langsung keluarkan dan direkonstruksi ulang menjadi sinyal analog agar dapat dikeluarkan melalui speaker yang ada pada penerima.

\subsection{Perancangan Skema Elektronik}

Perancangan skema elektronik diawali dari suara yang masuk melalui MAX9814 yang merupakan microphone dengan sistem auto gain control (AGC) diatur penguatannya menjadi $40 \mathrm{~dB}$ [8] dengan memberi tegangan 5V (tegangan yang sama dengan Vcc pada MAX9814) pada kaki Gain Max9814 dan masuk melalui pin A0 pada mikrokontroler Robotdyn Nano V3. Data yang masuk akan dikonversi menjadi data digital dalam bentuk deretan bilangan integer oleh mikrokontroler dan 
diserahkan ke mikrokontroler Node MCU Lolin V3. Pengiriman data menggunakan protokol komunikasi serial peripheral interface (SPI) melalui pin D5, D6, D7, dan D8 pada mikrokontroler Node MCU, serta pin 13, 12, 11, dan 10 pada mikrokontroler Robotdyn. Data yang dikirimkan melewati IC logic level agar tegangan keluar $5 \mathrm{~V}$ pada mikrokontroler Robotdyn diubah menjadi 3,3V yang merupakan tegangan standar dari Mikrokontroler Node MCU. Selanjutnya data integer yang diterima mikrokontroler Node MCU akan ditransmisikan melalui BLE HC-42 [9] menggunakan pin UART0 pada mikrokontroler Node MCU yaitu RX0 dan TX0. Setelah dikirim data digital akan diterima oleh HC-42 bagian penerima lalu diteruskan ke mikrokontroler Node MCU. Setelah proses pengiriman data akan langsung diubah menjadi deretan bit dan dikeluarkan melalui pin D2 pada mikrokontroler Node MCU. Data bit yang keluar akan diubah menjadi data analog kembali menggunakan rangkaian low pass filter [10] dan dihubungkan ke port jack input. Adapun skematik rangkaian elektronik yang dirancang dapat dilihat pada Gambar 2.

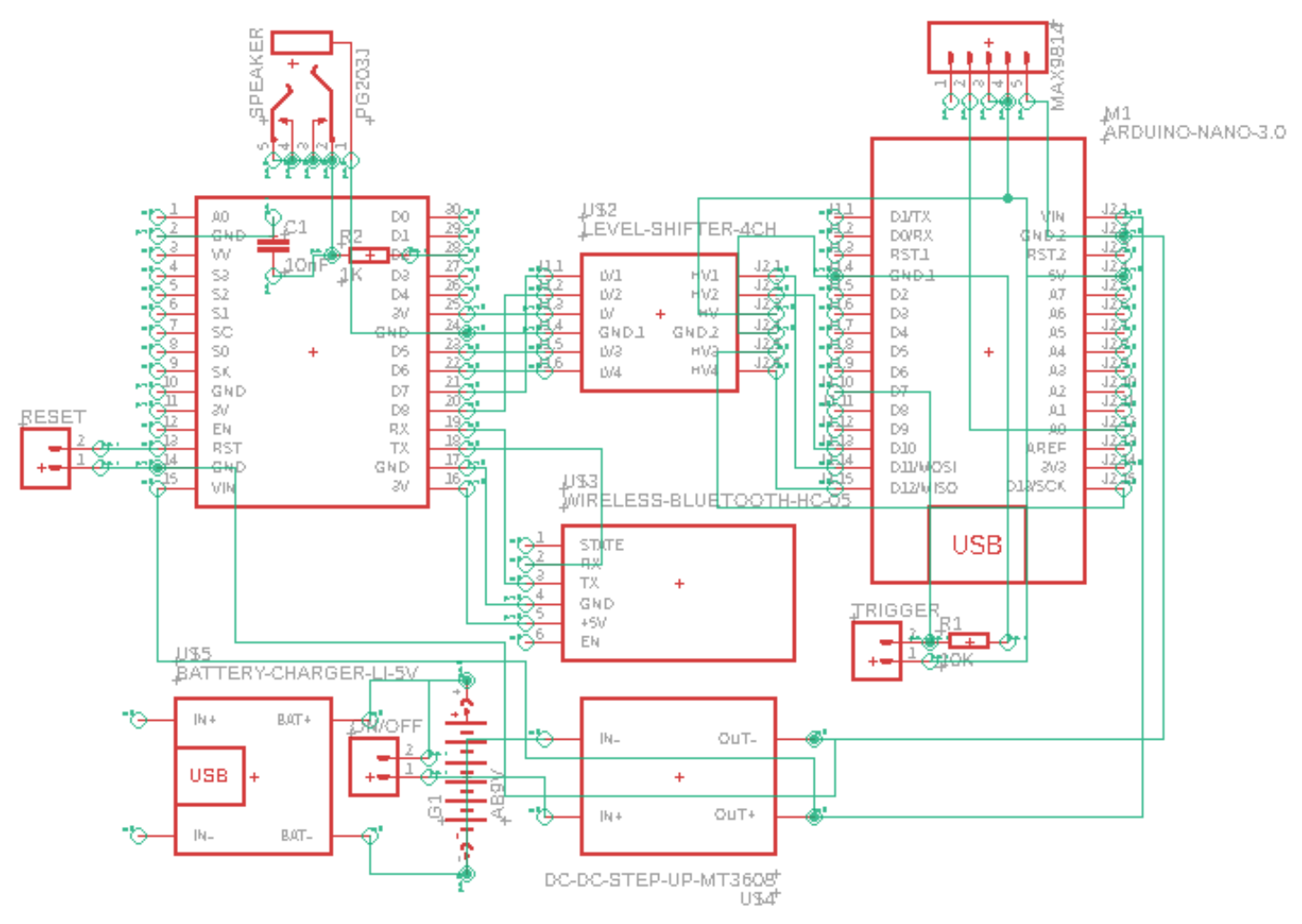

Gambar 2. Skema elektronik sistem

\subsection{Perancangan Algoritma}

Gambar 3 menunjukkan diagram alir dari perancangan algoritma. Sinyal suara berupa sinyal analog diterima melalui microphone yang selanjutnya akan dilakukan sampling sinyal untuk mengubah data analog menjadi data digital. Suara yang didengar memiliki range frekuensi $20 \mathrm{~Hz}$ sampai $20 \mathrm{KHz}$ dan dibagi menjadi tiga bagian yaitu low audio dengan frekuensi maksimal $4 \mathrm{KHz}$, high audio dengan frekuensi maksimal $8 \mathrm{KHz}$, dan full audio dengan frekuensi maksimal sama dengan frekuensi maksimal yang dapat didengar manusia normal yaitu $20 \mathrm{KHz}$. Sampling sinyal audio yang dipilih adalah $16 \mathrm{KHz}$ untuk sampling data suara yang akan masuk ke mikrokontroler Robotdyn (dua kali frekuensi high audio berdasarkan Teorema Nyquist) [11]. Selanjutnya data digital yang diterima dalam bentuk integer ditransmisikan menggunakan protokol SPI ke mikrokontroler Node MCU dengan kecepatan transmisi 1 Mbps. Data yang diterima Node MCU langsung dikirim ke bagian penerima dengan BLE dengan baudrate 115200. Lalu data yang diterima oleh mikrokontroler Node MCU bagian penerima akan dikeluarkan melalui pin pulse width modulation (PWM) sebagai bentuk dari besaran dutycycle dari masing-masing bit yang sebelumnya sudah dipetakan dari 0 Sampai 1023. 

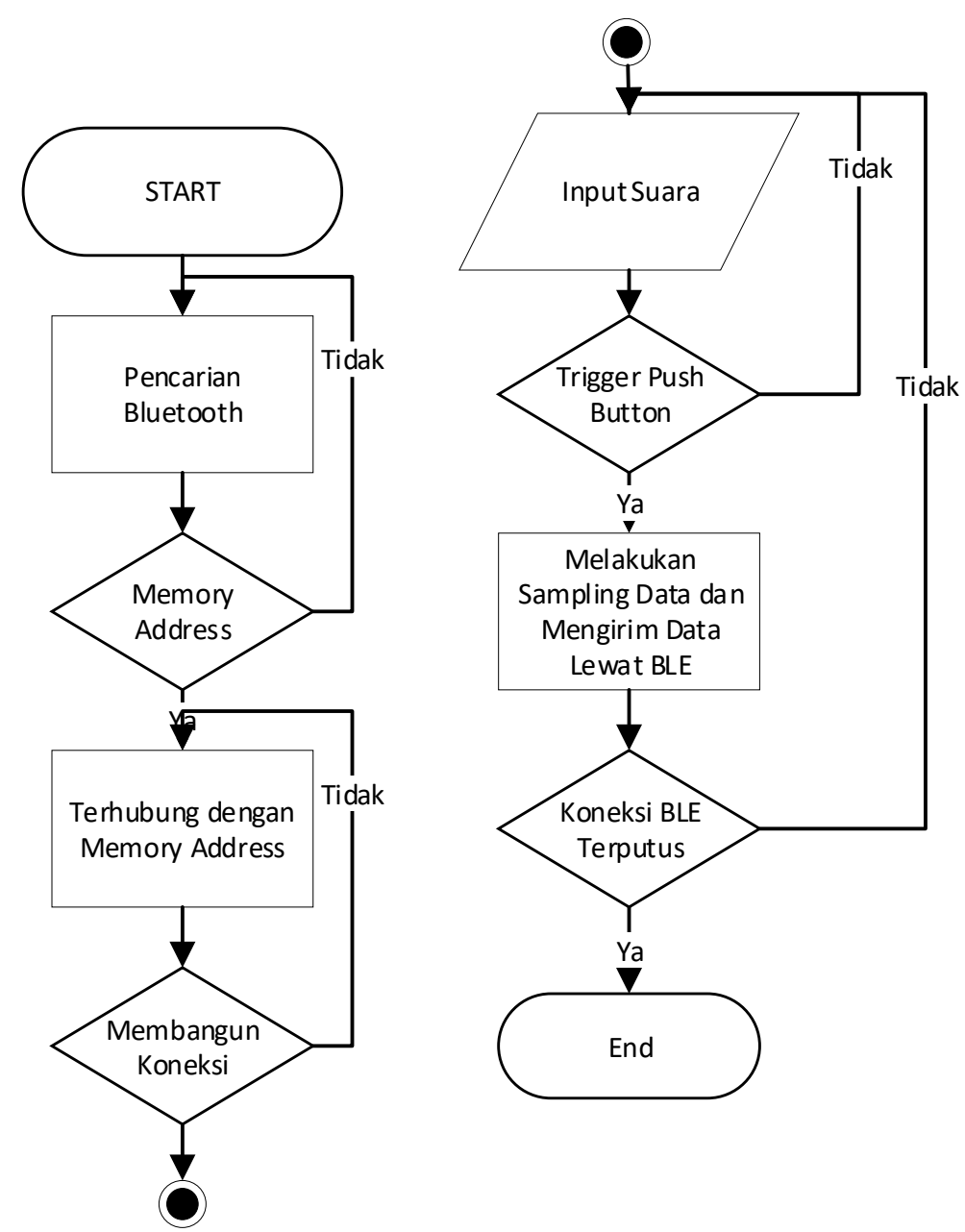

Gambar 3. Flow chart cara kerja sistem

\subsection{Realisasi Perangkat Keras}

Perakitan dilakukan setelah realisasi printed circuit board (PCB) berhasil dibuat dan sistem dapat berjalan. Perakitan dilakukan dengan memasukkan PCB dan komponen-komponen utama yang melekat pada PCB ke dalam box hitam dengan ukuran 7,5 x 10 × $3 \mathrm{~cm}$. Selanjutnya dilakukan tata letak komponen tambahan berupa suplai daya baterai dan push button pada luar box seperti yang ditunjukkan pada Gambar 4.

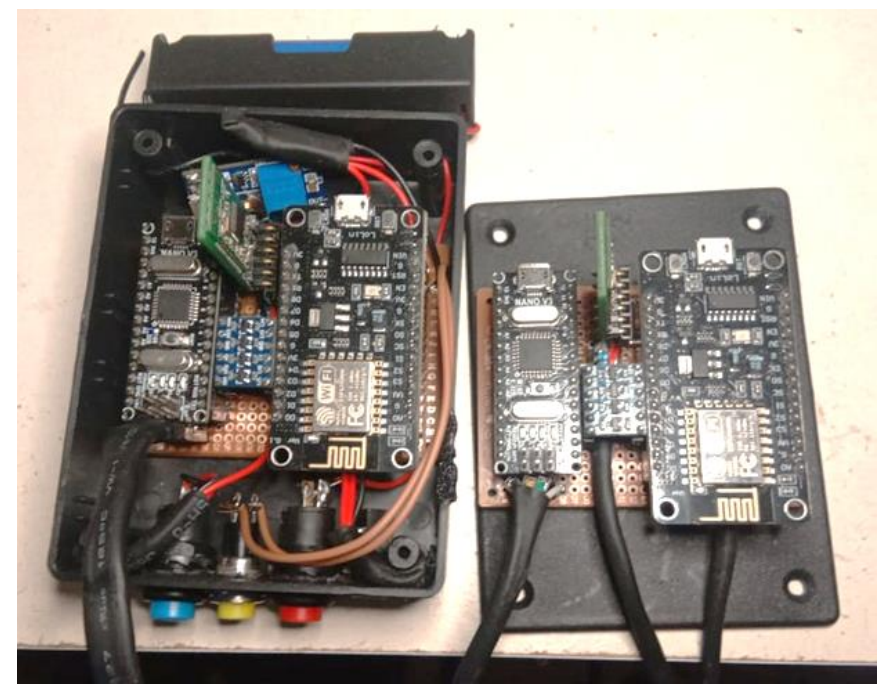

Gambar 4. Realisasi perangkat keras 


\section{HASIL DAN PEMBAHASAN}

\subsection{Delay/Latency}

Pengukuran delay/latency ini dilakukan dengan menghubungkan bagian penerima untuk dihubungkan ke laptop melalui kabel jack audio in pada laptop seperti yang sudah dijelaskan pada bagian gambaran pelaksanaan pengujian. Dengan menggunakan software Audacity, Gambar 5 adalah hasil percobaan dengan mengubah parameter sampling pada register ADCRSA ATmega328P dengan kecepatan clock SPI 1 Mbps.

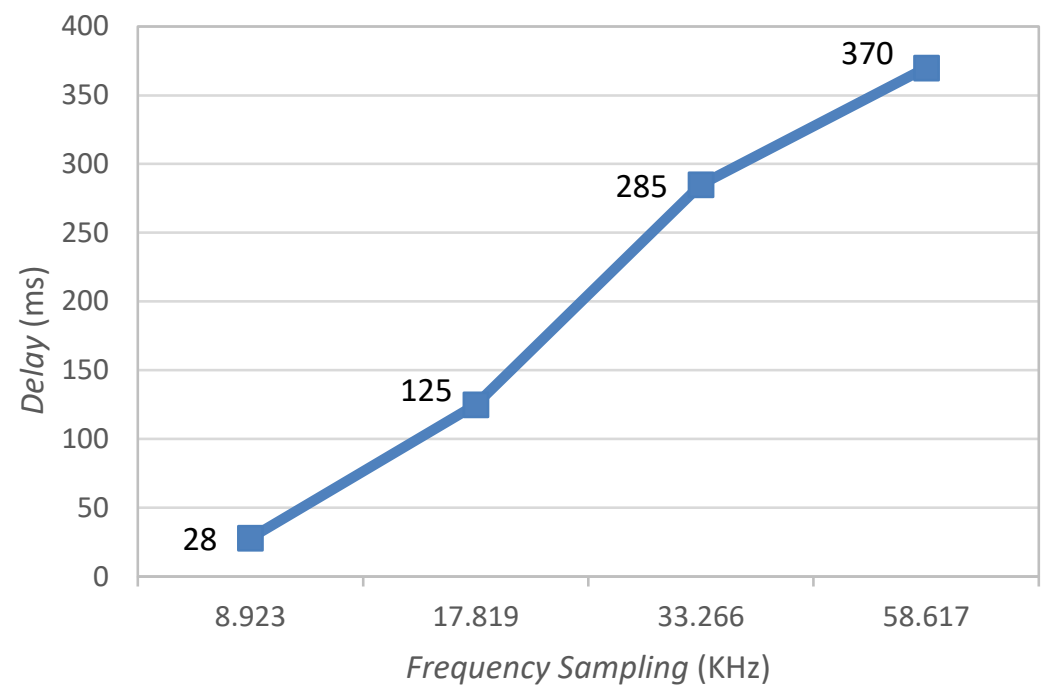

Gambar 5. Grafik delay/latency

Pada Gambar 5 terlihat pengaruh sampling rate terhadap waktu tunggu sinyal informasi yang diterima pada setting protokol SPI di 1Mbps. Dapat terlihat semakin tinggi sampling rate yang ditentukan maka semakin tinggi pula waktu informasi sampai ke bagian penerima. Hal ini disebabkan oleh tingginya penggunaan CPU pada ATmega328P untuk digunakan melakukan sampling rate (ADC prescaler yang membagi/mengambil waktu dari CPU ATmega328P). Nilai dari frekuensi sampling rate dalam mengatur register ADCRSA pada ATmega328P dapat dilihat dari penelitian [12]. Pemilihan protokol SPI pun didasari oleh keterbatasan kecepatan clock pada CPU ATmega328P $(16 \mathrm{MHz})$. Penggunaan langsung protokol UART untuk menggunakan BLE dan mengirim informasi dengan baudrate 115200 tidak dapat diterima oleh bagian pengirim sehingga diharuskan menambah rangkaian buffer berupa penyimpan (penyimpanan external) agar processor dapat membagi waktu sampling rate oleh $\mathrm{ADC}$ dan bagian pengiriman. Cara ini akan menambah waktu tunggu dalam pengiriman sehingga informasi tidak dapat diterima secara real-time. Dengan demikian, pada penelitian ini dibagi tugas antara dua mikrokontroler dengan protokol SPI. Adapun protokol lain seperti I2C yang menggunakan pin analog pada mikrokontroler Robotdyn sudah diuji coba oleh penulis dan mendapat hasil kurang sempurna karena pin analog pada ATmega328P digunakan untuk samping dan pengiriman informasi yang menyebabkan banyak bit yang salah.

\subsection{Pengukuran Kestabilan Sistem}

Pengukuran kestabilan sistem dilakukan dengan proses maupun parameter yang sama dengan pengukuran delay/latency. Perbedaan ada pada nilai yang dilihat yang mana pengukuran kestabilan sistem melihat lama waktu sistem melakukan transmisi sampai terjadi kegagalan transmisi yang ditandai oleh berubahnya nilai amplitudo secara drastis. Hasil percobaan dengan mengubah parameter sampling pada register ADCRSA ATmega328P dengan kecepatan clock SPI 1 Mbps dapat dilihat pada Gambar 6. 


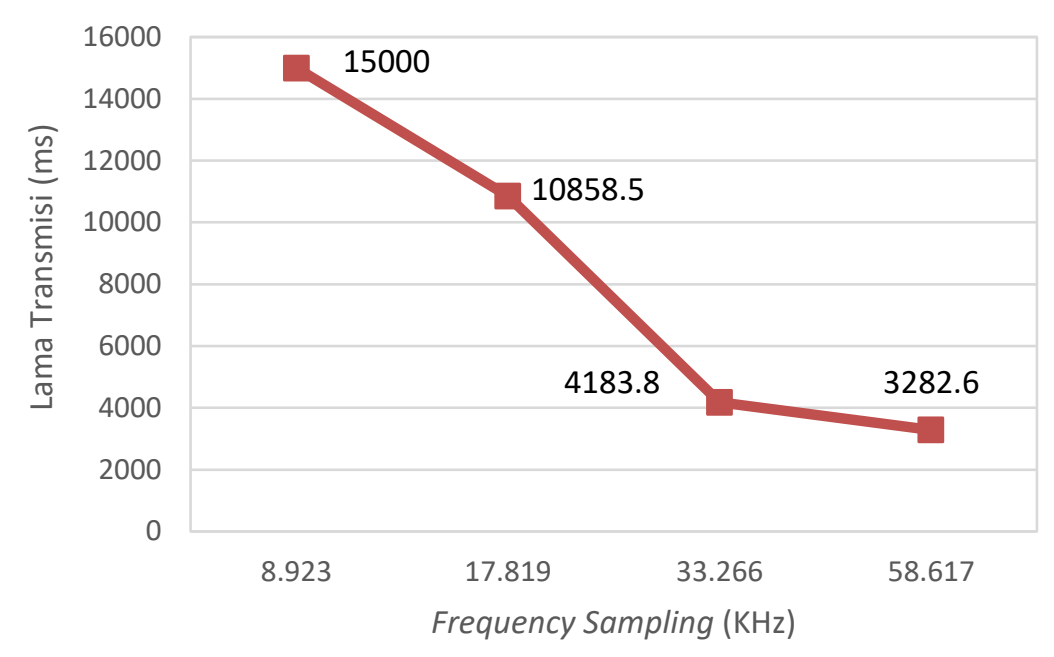

Gambar 6. Grafik kestabilan sistem

Pada analisa kestabilan sistem ini dapat terlihat menggunakan grafik Gambar 6. Semakin tinggi sampling rate yang dipilih untuk mikrokontroler Robotdyn, maka semakin sebentar waktu informasi yang dapat dikirimkan. Cara perhitungan kestabilan sistem ini adalah dengan melihat waktu push button pada software Audacity yang ditandai dengan naiknya nilai amplitudo secara maksimal, dilanjutkan dengan sinyal informasi yang dikirimkan, dan diakhiri oleh sinyal noise pertama. Sinyal noise ini berupa peningkatan amplitudo secara mendadak dan bila diteruskan akan membentuk pola yang sama sehingga informasi yang diterima terganggu oleh nilai amplitudo tersebut. Masalah noise ini sudah dilakukan penelitian sebelumnya dengan melakukan percobaan pada bagian pengirim dengan melepas BLE dan melihat diagram pottle dari software Arduino IDE menggunakan USB UART. Lalu ditemukan bahwa bagian pengirim tidak terdampak pada noise ini, sehingga disini dapat didiagnosis bahwa masalah ada pada bagian pengiriman atau bagian penerimaan.

\subsection{Pengukuran Daya}

Pengujian terakhir dilakukan pada konsumsi daya sistem. Pengujian dilakukan dengan melihat daya yang digunakan oleh sistem selama masa idle/diam (sistem tidak mengirim atau menerima informasi), pengiriman (sistem melakukan sampling dan transmisi secara bersamaan), dan penerimaan (sistem menerima informasi dari pengirim dan melakukan output berupa sinyal suara pada speaker).

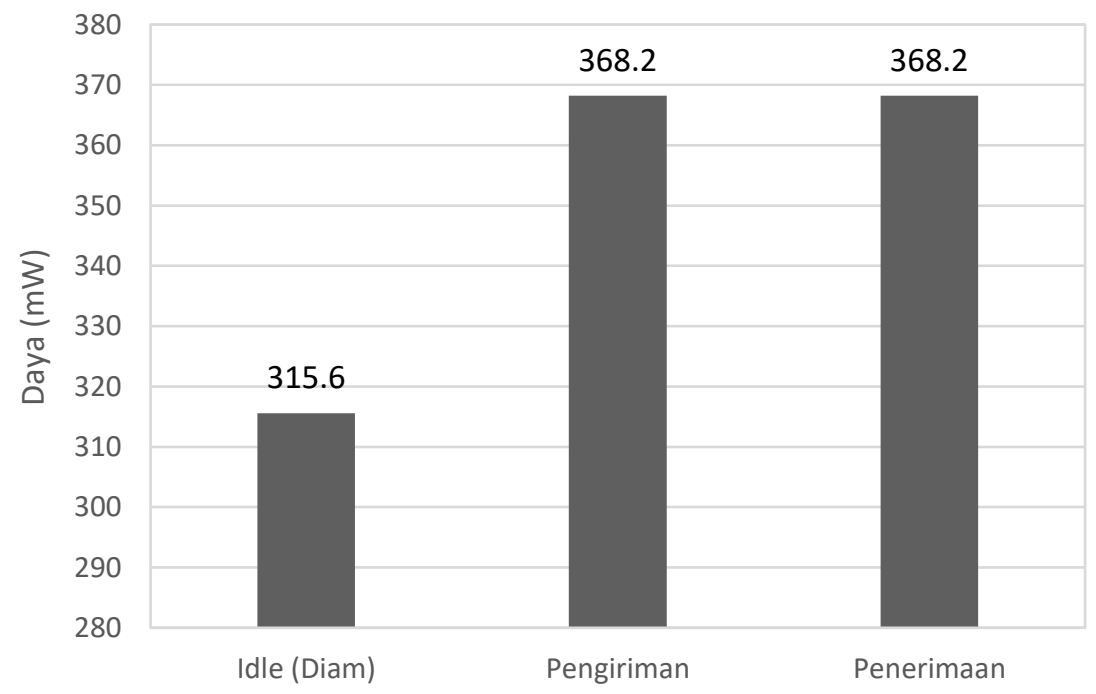

Gambar 7. Grafik konsumsi daya 
Pada Gambar 7 dapat dilihat konsumsi daya pada tiga keadaan yang terjadi pada bagian pengirim maupun penerima. Konsumsi daya pada saat keadaan idle (diam) adalah 315,6 mW, sedangkan daya yang digunakan selama masa pengiriman maupun penerimaan adalah $368,2 \mathrm{~mW}$. Konsumsi daya ini sebagai besar digunakan untuk sistem yang menopang dua mikrokontroler, sedangkan untuk HC-42 sendiri menggunakan arus maksimal 1,23 mA dengan tegangan kerja maksimal 3,6 V [9]. Konsumsi ini lebih kecil dibandingkan penggunaan bluetooth konvensional HC-05 dengan arus kerja maksimal $30 \mathrm{~mA}$ dan tegangan kerja maksimal 6,0 V [13]. Ini dapat terjadi karena penggunaan bluetooth yang berbeda dimana pada percobaan ini BLE yang digunakan adalah V5.0 yang merupakan versi terbaru untuk masa sekarang.

\section{KESIMPULAN}

Komunikasi suara secara real-time untuk aplikasi pengendara roda dua dapat dilakukan dengan menggunakan BLE HC-42 dengan sampling rate $17,819 \mathrm{KHz}$ dan baudrate 115200 bps secara bergantian dari pengirim ke penerima ataupun sebaliknya (komunikasi half duplex). Hasil uji coba delay/latency yang diterima sebesar $125 \mathrm{~ms}$ lebih kecil dibandingkan ketentuan delay maksimal komunikasi suara menurut ITU-T G.114 sebesar $150 \mathrm{~ms}$ [14]. Kestabilan sistem mendapat lama waktu sebesar 10858,5 ms, dan konsumsi daya sebesar 315,6 mW sampai 368,2 mW. Saran untuk penelitian selanjutnya menggunakan mikrokontroler yang dapat melakukan sampling frekuensi > $16 \mathrm{KHz}$ dan dapat melakukan transmisi dengan baudrate 115200 secara bersamaan. Jika tidak memungkinkan dapat mencoba menggunakan mikrokontroler Arduino Nano 33 BLE Sense [15] untuk mengurangi konsumsi daya dan penggunaan komponen $\mathrm{HC}-42$.

\section{REFERENSI}

[1] Badan Perencanaan \& Pembangunan Daerah Daerah Istimewa Yogyakarta, "Data Kecelakaan dan Pelanggaran Lalu Lintas," [Online]. Available: http://bappeda.jogjaprov.go.id/dataku/data_dasar/index/548data-kecelakaan-dan-pelanggaran-lalu-lintas?id_skpd=39. [Diakses 23 July 2021].

[2] A. B. Wijaya and A. S. Khalilullah, "RANCANG BANGUN ALAT PENGUKUR DETAK JANTUNG DAN SUHU TUBUH MANUSIA BERBASIS KOMUNIKASI BLUETOOTH,” Seminar Proyek Akhir Jurusan Teknik Telekomunikasi PENS-ITS 2010, pp. 1-4, 2010.

[3] A. Syofian, "Perancangan Pengendali Rumah menggunakan Smartphone Android dengan Konektivitas Bluetooth," Jurnal Teknik Elektro ITP, vol. 5, no. 1, pp. 45-50, 2016.

[4] M. A. Nugroho, S. Sumaryo, and Estananto, "DESAIN DAN IMPLEMENTASI HELM PINTAR DENGAN FITUR BLUETOOTH,” eProceedings of Engineering, vol. 6, no. 2, pp. 2609-2616, 2019.

[5] W. Zhengyan, Y. Wei, S. Xingling, and Z. Hongqiang, "Design and Research about Voice Communication System Based on Bluetooth," in IEEE 2011 Third International Conference on Measuring Technology and Mechatronics Automation, Taiyuan, 2011, pp. 911-914.

[6] N. Kajikawa, Y. Minami, E. Kohno, and Y. Kakuda, "On Availability and Energy Consumption of the Fast Connection Establishment Method by Using Bluetooth Classic and Bluetooth Low Energy," in Fourth International Symposium on Computing and Networking, 2016, pp. 286-290.

[7] R. Faragher and R. Harle, "Location Fingerprinting With Bluetooth Low Energy Beacons," IEEE JOURNAL ON SELECTED AREAS IN COMMUNICATIONS, vol. 33, no. 11, pp. 2418-2428, 2015.

[8] Maxim Integrated, "MAX9814," https://www.maximintegrated.com/, San Jose, 2009.

[9] Guangzhou HC Information Technology Co., Ltd, "User Manual for HC-42 Bluetooth Serial Port Module," www.hc01.com, Guangzhou City, 2018.

[10] G. D. Colletta, L. H. Ferreira, T. C. Pimenta, and P. C. Crepaldi, "A successive approximation a/d converter using a pwm modulator dac," in 2012 IEEE Ninth Electronics, Robotics and Automotive Mechanics Conference, 2012, pp. 333-337.

[11] C. Greening, "ESP32 Audio Input Using I2S and Internal ADC," 18 August 2020. [Online]. Available: https://www.cmgresearch.com/. [Diakses 28 April 2021].

[12] S. Silva, A. Valente dan S. T. Marcelino, "Digital Sound Processing using Arduino and MATLAB," in 2015 Science and Information Conference (SAI), 2015, pp. 1184-1191.

[13] Q. I. Khan, "Muscle Controlled Robotics with Special Reference to a Car," Final Project University of Engineering and Technology, 2018.

[14] M. Voznak, A. Kovac, and M. Halas, "Effective packet loss estimation on VoIP jitter buffer," in International Conference on Research in Networking, Berlin, 2012, pp. 157-162.

[15] A. Kurniawan, "Arduino Nano 33 BLE Sense Board Development," in IoT Projects with Arduino Nano 33 BLE Sense, Apress, Berkeley, CA, 2021, pp. 21-74. 
